\title{
Néstor García Canclini e a questão do moderno na América Latina
}

\author{
Bruno Peron Loureiro ${ }^{1}$
}

A América Latina almeja o progresso, o desenvolvimento, a evolução, a ocidentalização e a modernização, mas sua trajetória tem enfrentado impasses e obstáculos e, não por acaso, os grandes comandantes do sistema acabam sendo beneficiados, sobretudo os europeus e norte-americanos. Estes exercem uma influência considerável nas condições materiais e espirituais da vida dos latino-americanos, dos patrimônios culturais, e das combinações entre passado e presente, muitas vezes anulando ou reformulando as heranças indígenas, africanas e ibéricas.

É inegável que a América Latina tenha-se modernizado, sobretudo no ingresso à década de 1990, em consequência do processo globalizador e da expansão célere e eficaz dos meios de comunicação e transporte. O problema é que a modernização ocorreu de uma forma distinta à que esperávamos décadas anteriores, pois a iniciativa privada assumiu o leme do processo, em vez do Estado, na segunda metade do século XX, e houve o recrudescimento das desigualdades em quase todos os países latino-americanos.

Neste contexto de dúvidas e incertezas quanto à história dos países latinoamericanos, de apelo aos modelos de desenvolvimento e inserção nas relações internacionais, convém entrar no campo teórico construído por Néstor García Canclini, que, embora não seja um historiador, contempla discute tais questões por meio de um diálogo interdisciplinar e mais abrangente, ou seja, suas formulações perpassam várias áreas, como antropologia, sociologia, história, comunicação, arte, literatura, filosofia, economia e política.

Canclini nasceu na Argentina em 1939 e radicou-se no México desde 1976. Sua maturidade intelectual problematiza a globalização e seus efeitos nas culturas populares, que sobrevivem à modernidade mediante a hibridações e apropriação de bens simbólicos inerentes ao capitalismo e à indústria cultural. Portanto, teve a sensibilidade de tratar o

\footnotetext{
${ }^{1}$ Graduado em Relações Internacionais pela Universidade Estadual Paulista (Franca-SP). Trabalho de conclusão de curso com o título Nestor García Canclini e a questão do moderno na América Latina: entre o fracasso dos modelos e o desafio da construção do novo. Email: brunopl@terra.com.br.
}

ISSN 1679 - 1061 Revista Eletrônica da Anphlac - número 5 
fenômeno do hibridismo entre tradição e modernidade nas sociedades latino-americanas, dentro dos limites humanos, como poucos acadêmicos teriam condições de fazer, pois contextualiza outros debates.

Quanto ao seu país de origem, Canclini afirma que a Argentina teve políticas de perseguição e carecia de leis que reconhecessem e protegessem seu patrimônio. Porém, o autor valoriza as histórias nacionais latino-americanas como fonte explicativa de traços atuais, a partir de sua experiência no México, que preserva tradições e monumentos, museus de altos investimentos e antigas festas camponesas que se reproduzem também nas cidades, como outros poucos países deste subcontinente fazem.

A partir da trajetória da América Latina, Canclini descreveu e sintetizou quatro projetos ou movimentos básicos da modernidade (democratizador, expansionista, renovador e emancipador). Acresce-se que a modernização e os modernismos não se desenvolveram do mesmo modo nos países latino-americanos, por isso pode ser uma tarefa complicada tomar o continente como unidade de análise, embora haja traços comuns importantes e processos históricos simultâneos que possibilitam tratar a América Latina como um todo e não como singularidades.

O projeto emancipador remete à secularização dos campos culturais, à produção autoexpressiva e autorregulada das práticas simbólicas, e seu desenvolvimento em mercados autônomos. O projeto expansionista trata da tendência da modernidade a estender o conhecimento, o controle e a posse da natureza, da produção, da circulação e do consumo dos bens. O projeto renovador defende um aprimoramento e inovação incessantes próprios de uma relação com a natureza e a sociedade, liberada de toda prescrição sobre como deve ser o mundo. Por sua vez, o projeto democratizador é o movimento da modernidade que acredita na educação, na difusão da arte e dos saberes especializados, para conquistar uma evolução racional e moral na tentativa de abarcar a todos.

Contudo, após a elucidação de cada um dos projetos da modernidade tratados por Canclini, devemos anotar o diagnóstico final elaborado pelo próprio autor, que permite entrevero fracasso dos modelos e introduzir a problemática do moderno no desenvolvimento da América Latina. Canclini já asseverou que os projetos da modernidade tornaram-se contraditórios, pois os movimentos culturais que procuraram combinar sua 
vocação emancipadora e renovadora com a democratização de suas novas experiências diluíram-se em promessas mal cumpridas enquanto tiveram que lutar contra vestígios oligárquicos e autoritários.

Canclini aponta que a modernidade ainda não terminou de chegar à América Latina, ou seja, os avanços modernos não chegaram totalmente nem para todos. Inclusive, o progressismo evolucionista e o racionalismo democrático não têm sido causas populares entre nós; não tivemos uma industrialização consistente, nem uma tecnificação ampliada da produção agrária, nem um ordenamento sociopolítico baseado na racionalidade formal e material.

Outra dificuldade consiste em impulsionar a modernidade cultural quando a modernização socioeconômica é tão desigual. Embora o liberalismo e seu regime de representatividade parlamentar tenham alcançado as constituições latino-americanas, falta uma coesão social e uma cultura política moderna e suficientemente consolidada para que nossas sociedades sejam governáveis. Alguns historiadores da arte concluíram que os movimentos inovadores são desconectados de nossa realidade e, por isso, considerados "transplantes" e "enxertos".

É com destreza que Canclini lida com a totalidade latino-americana sem negligenciar as heterogeneidades no gênero de modernidade que se processou nos vários países, embora extraia boa parte de seus argumentos do México, Argentina e Brasil. Para o autor, o projeto modernizador, da forma como está sendo conduzido, gera consumidores em lugar de cidadão se não permite a democratização dos bens e serviços. Há indícios de um triste diagnóstico do momento histórico vivido pela América Latina.

As obras de Canclini permitem cotejar os modelos implantados na América Latina com o questionamento do que teria sido melhor para o seu processo de desenvolvimento. Em outras palavras, a dúvida é: se, para construir o novo, este subcontinente deve imitar ou buscar elementos tradicionais e nativos na confecção de seu próprio destino. Canclini não insiste em considerações políticas já conhecidas, mas discute os latino-americanos como "produtores, migrantes e devedores" através da compreensão dos processos culturais de seu tempo e da reconsideração dos modos de fazer arte, cultura e comunicação na época atual. 
Houve uma confiança cega nestes modelos e uma crença de que seriam proveitosos para o desenvolvimento do subcontinente, como reflexo do sucesso conquistado pela modernidade nos países desenvolvidos. Contudo, a realidade era outra. Por conseguinte, infere-se a dilemática irrealização destes projetos ou movimentos básicos da modernidade conforme esboçados por Canclini, e o consequente desafio para se construir o novo na América Latina, pressupondo-se a dificuldade das reformas estruturais e de acomodação do moderno.

ISSN 1679 - 1061 Revista Eletrônica da Anphlac - número 5 